\title{
A CONSTRUCTIVE PEACE POLICY FOR AMERICA
}

\section{By J. Pease Norton,}

Professor of Railway and Trade Statistics, Harvard University.

Never in all the ages recorded by the historians of the past have the nations of the earth paused upon the threshold of an era so full of promise. Wonderful inventions together with signal advances in social organization are making a new world. One cloud alone looms black and portentous - the war cloud which in the twinkling of an eye may break into the storm which will impoverish whole nations and defeat the progress of a thrifty generation. Only by clearly discerning the dangers can such conditions be handled adequately, even by our wisest statesmen.

The United States is no longer an isolated country. To the west, we have flung our battle-lines to meet the expansion of the Orient in the Philippines. At Behring Strait, our sentries watch the frontiers of the Czar. On the south at Panama, we clutch by the throat the passageways for the navies of two oceans. Our armies of occupation are now holding by force of arms our outlying possessions. Like the Romans of old, we send forth our governors to rule over the millions of our alien subjects. In this imperial development concerning which discussion apparently no longer can exist because the flag once flying is not easily withdrawn, a greater and a greater care must be exercised lest our defenses are unequal to the probabilities of future danger.

The United States is no longer an isolated nation. Our country has become the storm center of the world. The present silence is suggestive,---almost expectant like the calm before the storm, to be followed by sudden rattling peals we know not when.

Statesmanship consists in the resolution of conflicting racial forces by constructive peace policies in advance of violent disturbances. War is the conflict of unstable racial forces, often caused by the economic pressure of population upon subsistence, always in search of a more stable equilibrium. The fundamental facts of racial geography should influence our determination of a constructive peace policy for America. Take in your left hand a small globe of the world 
and place the thumb of your right hand upon Peking, the index finger at Behring Strait, the second finger upon St. Louis and the little finger at New Orleans. Note carefully the relative distances between points in the interior of China and points in the interior of America, first, by the way of the Behring Strait and, then, by way of the Pacific Ocean through San Francisco and Asiatic ports. In the language of relative distances, fundamental geographical and racial principles are often stated. Considering the geographical situation of the United States, does not reason declare that it is more important for us to command the land than the sea? A French engineer, M. Loncq de Lobel, at the International Congress of Arts and Sciences in 1904, suggested that it is possible to tunnel the Behring Strait. Within a few weeks, Congress has appropriated $\$ 35,000,000$ for the construction of one thousand miles of railway in Alaska. The Russian government has considered favorably the project suggested by Lobel, to extend the Siberian Railway toward the Behring Strait.

Let us add to the great wonder of the world now created at Panama, a second wonder, more wonderful and more far-reaching. Just as we have linked together the oceans, let us link together the continents of the world. Let it be said in history that one and the same nation, which at Panama put asunder two continents that nature had joined together, still not content with one colossal task straightway at Behring Strait joined together two continents which nature had left asunder. The question whether it is possible for our engineers to construct such tunnels should be left for them to decide. When one contemplates the tunnel work of tbe Simplon, the work of constructing the tubes underlying Manhattan and the North and East Rivers, including the great bores of the Pennsylvania Railroad, the work does not seem either impossible or impractical from the standpoint of capital expense.

That the land is more important than the sea seems evident when we consider geographically the route by which our nation may invade the East, if ever it shall be necessary for the purposes of defense. The very possibility of war is a calamity, more grievous than mind can tell. Yet national policies should provide for all possibilities. If in an unfortunate tide of events we must carry the war into Asia, let us carry it by land and not by sea.

But, far more than this advantage in times of war, such a policy should be the guarantee of lasting peace. Through these tunnels, 
great inter-continental railroads would thread their way. The building of the Alaskan Railway has already been provided for by the present Congress. By this railroad and possible future tunnels, five continents will be joined. For the traveler of the twentieth century, there will be "no more sea." Such continental railways will become the arteries of commerce. In times of peace, the railways will be trade routes of the world. In times of war, the railways will prove of value in ways which are apparent. By them, vast bodies of troops could be quickly assembled, their strength properly massed and the current of adequate supplies constantly maintained. Often as in the career of men, so in the lives of nations, crises are turned by wise policies which are adopted long before the real difficulties are reached.

What, then, should constitute a constructive peace policy for America? At this juncture, he who would think ahead, after contemplating the facts-geographical, racial, economic, sociological and national-irresistibly driven by the logic of the situation is forced to say: why not make for a long world peace by a new triple alliance, the United States, Russia and China-three great nations representing three civilizations, diverse races, yet common in three essentials: all are land powers; all meet at Behring Strait figuratively speaking; all are interested in internal development rather than in geographical expansion. Why not make treaties mutually defending the integrity of the domains of each? By such an alliance, war might be prevented for many years and the swift march of progress might carry our civilization many leagues onward in the great uplift which otherwise may be impeded, if not prevented, by those internecine combats which have drawn the life-blood from all the departed nations of the past, whether temporarily the victors or the vanquished, it mattered not. We may not estimate the value of a peace, guaranteed principal and interest, to China, to Russia and to the world. A wonderful development is in store for China. Russia has the great future filled with opportunity. The United States has a dream to work into a reality, a civilization which will stretch from Behring Strait to Panama. The Panama Canal was the inception. The Alaskan Railway and the Behring tunnels should be the greater conception and the new triple alliance should bring with it lasting peace.

Let us reason carefully without regard to precedent, and strictly in accord with the interest of the great future which holds in store 
such splendid opportunities for intensive development by all nations and by all races. We occupy the heart of North America. We own Alaska, Panama and some of the islands of the sea. To the south, there lives an unhappy people, now greatly troubled by a distressing civil war. To the north, there is a kindred people. Their needs are our needs. War has come to the people of the South, because the government of the past thirty years failed to bring to the common people the great blessings of free public education, protection to life and property, local self-government and a system of small freehold properties in place of the great landed estates. A protectorate by the United States over Mexico and Central America conceived in the spirit of the higher patriotism with patient watchfulness for the purpose of insuring to each province the benefits of an equitable system of taxation, an honest administration, free elections, free public education and proper protection to life and property, would make for a lasting peace in North America. Without such a protectorate, every flighty despo $t$ wafted into Mexico City by some hot-headed impulse of an uneducated and distracted people becomes a ready tool for the political schemesters of foreign nations, to be manipulated for the purpose of securing concessions and colonies. In the past, we have written the Monroe Doctrine in figures of iron. If these principles which are fundamental to a constructive peace for North America cannot be seen clearly as yet by all nations, let us trace these principles in letters of fire: North America for North Americans and withal peace, order, education, protection to life and property, lasting prosperity.

Let us go further and help to establish the peace of the world, by means of a new triple alliance to include Russia, China and the United States, seven hundred millions of people, an alliance for the mutual defense of the integrity of the domains of each nation. Let us control the new tunnels under the auspices of the triple alliance. Let us say to all the world: We ask only peace and fair commerce. Our good will goes out to all. Our destiny is in North America and in the islands of the North American continent. There our rule shall be sufficient to insure security to all. We do not want the Philippines. They are too far removed from the land of our destiny. We await an honorable release. Shall we not give them over into their own hands, a republic under the protection of the triple alliance? Having established through such an alliance a lasting peace which 
no nation would care to controvert, the severe economic pressure now felt by Japan could be relieved by a more intensive application of the recent advances in the arts, again through a reduction in the excessive appropriations for a navy and, finally, by emigration to friendly countries.

Let us open our doors to the immigration from all nations, restricted fundamentally in accordance with the statistical principles of the eugenic melting-pot, namely, that in any one year the number of immigrants shall not be greater than 2 per cent of our population and that the number from any nationality shall not be greater than that fraction of 2 per cent which the population of the given nationality now in our country bears to the entire population of the United States.

At home, let us look sharply to the objects for which go the enormous appropriations for the army and the navy. Let us hold that the sum we give for national defense is not too great, but rather that what we get in return is much too little. As we follow the careers of successive sessions of Congress, all bent upon vast appropriations and following constantly in the track of their predecessors, dimly at times there are those of us who have wondered whether tradition does not play too great a rôle at Washington. Let us interpret rightly the truth expressed in these words:

Were half the power that fills the world with terror,

Were half the wealth bestowed on camps and courts,

Given to redeem the human mind from error,

There were no need of arsenals or forts.

To obtain more utility from what we spend should be our purpose. We reform by substitution more easily than by prohibition. The following quotation clearly describes the wastes which have long been with us:

"Change the scene," said Charles Sumner one day at Harvard College, "and cast your eyes upon another object. There now swings idly at her moorings in this harbor a ship of the line, the Ohio, carrying ninety guns, finished as late as 1836 at an expense of $\$ 548,000$, repaired only two years afterwards for $\$ 233,000$, with an armament which has cost $\$ 54,000$, making an aggregate of $\$ 835,000$ as the actual outlay at this moment for that single ship, more than $\$ 100,000$ beyond all the available wealth of the richest and most ancient seat of learning in the land." 
How small these figures look in comparison with the figures of today. Today as then a battleship at $\$ 14,000,000$ costs more than the foundation of Yale University. Possibly $\$ 15,000,000,000$ has been expended upon the United States navy during the last twenty years. For the world, the costs of standing armies are no less astounding than depressing. In 1906 the amount expended by twenty nations reached $\$ 17,000,000,000$. New inventions are making battleships obsolete for a continental power. An air-ship capable of dropping explosives can be built for $\$ 2,000$. One battleship at $\$ 14,000,000$ cost as much as seven thousand air-ships. What convoy of battleships threatening New York or San Francisco could withstand the hail of dynamite from these hostile hornets of the air, ten to twenty thousand in number, flying by day just above the clouds and by night just beneath the stars?

We should adopt a no-battleship program and appropriate ten millions, at least, annually for aero-nautical defense. One-half of this should be used as subsidy to increase the number of the owners of hydroplanes along our seacoast, to be classed as the aero-nautical reserve.

Finally, let us link up our army expenditures with education and vocational training. The army reserve should consist of two million men. Such a number we should build up in twenty years by establishing the standing army at four hundred thousand, consisting of young men who may wish to attend high schools giving vocational training, universities, scientific schools or industrial colleges. At least two self-sustaining trades should be taught each man in addition to his regular training. The man should have the privilege of choosing his trades from a broad list. The arts of war, rifle practice, marching and drilling, can readily be taught to small companies of selected boys who are living for the first two years at their own homes, assuming the term of enlistment to be four years. Cross country work can be accomplished in vacations. The expenditures for the army by this plan become simultaneously a subsidy to education. Exceptional boys in all the schools of the country, above fifteen years in age, would then have adequate opportunity of securing a vocational or higher education under a fair system of civil service examinations, and the country would have an army reserve of one million men at the end of ten years, two million at the end of twenty years, every man of them with two self-sustaining trades. 
In summary, then, a rough outline of a constructive peace policy for America has been sketched, involving several radical departures. Among these, the plan of the peace enthusiasts for an Anglo-American alliance is not essential. The requirements of this analysis, outlining the essentials of a constructive peace policy for America are, first, a new triple alliance to include Russia, China and the United States; second, the construction of the Behring tunnels and the completion of our part of the inter-continental railway in Alaska, already commenced; third, a no-battleship program and a curtailment in naval expenditures; fourth, development of aero-nautical defense and the organization of an aero-nautical reserve; fifth, the development of the army reserve through the use of the army funds as a means of educating young men, especially in vocational training and in the arts of war; sixth, establishing once for all a statistical maximum limit for the annual immigration into the United States.

In this way, we shall perhaps most economically achieve the goal of a lasting peace, develop commerce, increase the opportunity of our people, mutually benefit with other nations and firmly construct the bulwarks of that impregnable security which is necessary to insure the intensive development of that magnificent area of the earth's surface which stretches from Behring Strait to the canal at Panama. 